\title{
A Qualitative Case Study of Gulf Coast Countries' e-Learning Policies in the Era of COVID-19
}

\author{
Alaa Jaber Zeyab, PhD \\ Assistant Professor at Public Authority for Applied Education and Training \\ PO Box 23167, Safat, 13092, Kuwait City, Kuwait \\ Tel: 956-99-802-329Ｅ-mail: dralaazeyab@gmail.com \\ Abrar S Almoosa, PhD \\ Kuwait Foundation for the Advancement of Sciences \\ PO Box 25263 Safat 13113 Kuwait \\ Tel: 956-99-464-460Ｅ-mail: aalmoosa@gmail.com
}

Amani M. Albaqshi, PhD

General Authority for Statistics

P.O. Box: 3735, Riyadh, 11481, Kingdom of Saudi Arabia

Tel: 699-56-900-5226E-mail: oza14@hotmail.com

\author{
Fatima Alabdullaziz, $\mathrm{PhD}$ \\ Mohammed Al-Mana College for Medical Sciences \\ PO Box: 3915, Dammam, 34222, Kingdom of Saudi Arabia \\ Tel: 669-50-510-8877Ｅ-mail: F.alabdullaziz@gmail.com
}

Received: May 17, 2021 Accepted: June 15, 2021 Published: June 30, 2021

doi:10.5296/ijld.v11i2.18653

URL: https://doi.org/10.5296/ijld.v11i2.18653 


\section{Abstract}

Long before the COVID-19 pandemic, there had been numerous disruptions of learning in recent history. In addition, educational systems are in crisis due to low-quality learning in terms of student outcomes in STEM fields, limited digital instructional resources for teacher training, and generally limited resources in low income countries. However, as of April 2020 , nearly $85 \%$ of students worldwide were out of school; that is 1.6 billion children kept home due to school closures in 180 countries. This paper explores how the Gulf Coast Countries (GCC) reacted to the disruption of education in order to understand the deeper issues of the rules and operations of educational systems and to provide recommendations to improve current education policies.

The COVID 19 pandemic has significantly affected day-to-day life in general and the learning setting in particular; this comes with temporarily closing schools, shutting down different campuses and learning institutions to maintain social distancing as has been advised by the national public health institutes and the Centers for Disease Control and Prevention (CDC). The new health measures have been forced on the world due to the spread of the novel coronavirus. Most schools have integrated different types of technologies as an alternative method to facilitate the learning process.

Keywords: Covid-19, emergency learning, distance learning, online learning, e-learning, GCC, school closures

\section{An Overview of the Education Crisis from 2005 - 2021}

Since 2005, a number of technologies and web tools have been developed and adopted in the teaching and learning processes. Among the significant changes is distance learning, where learners and instructors are separated physically but can come together through technological means (Annette, Folta, \& Klesath, 2010). The education sector stakeholders have held out hope for information and computer technologies (ICTs) to play a critical role in enabling the learning process to continue in order to serve students during crises such as wars, natural disasters, and diseases. Therefore, many schools introduced ICTs to allow reforms to and innovation within the traditional systems of education.

Taking the swine flu breakout in Mexico as a case study, we find that most schools implemented quick and systemically innovative reforms in 2009 (Chambers, Barker, \& Rouse, 2012). During this period, the Mexican educational system shifted to the use of television to broadcast the instructional process. China was also faced with a disease outbreak in 2009 (SARS) which resulted in closing schools to in-person learning. The government shifted to distance and online learning, using computers to facilitate the process.

When it comes to the response of the educational sector during a crisis, we find that the contemporary problems in education correlate to the stability of a country, taking into account both political and social institutions in most countries around the world (Cloete, Maassen, Fehnel, R.Moja, Gibbon, \& Perold, 2006). Worldwide, the schooling unit is moved to the household or other social institutions; this makes the educational system and process dependent on both political and social stability within a country. In many countries, political 
instability has affected the learning process (Devi et al., 2017).

Moreover, prior to COVID-19, recent studies by the World Bank have shown that in low income countries, 258 million primary-secondary school age students are simply not attending school. This fact, combined with a high student dropout rate due to socioeconomic issues and low quality education, indicate an already existing educational crisis.

The purpose of this study is to investigate the global response to COVID-19 in the educational sector in general, and in the GCC in particular, to better understand how to improve educational policies in order to minimize issues that might arise with future interruptions of education.

\section{Methodology}

A qualitative case study method is used for this research into e-Learning policies during Covid-19. The goal of this paper is to enhance our understanding of the given policy parameters for improving current educational policy, rather than to recommend one tool over another, so that in a crisis, schools and institutions can function based on the needs of students.

\section{Definitions}

\subsection{Definition of Distance Learning, Online Learning, e-Learning, and Mobile Learning}

Distance, online, mobile \& e-learning are nearly synonymous terms for any form of non face-to-face digitally-enabled learning.

According to Abdullah (2018, p.3), distance learning is defined as separating a teacher from a student and using media to facilitate the entire course content, whereby the teacher-student relationship is maintained through an information and communication technology that allows both to interact freely without face-to-face communication. More simply, distance learning is a form of learning that is internet-based (Donald, 2002, p.28).

According to Moore, Dickson-Deane and Galyen (2011, p.130), online learning is education delivered through modern technology over computer networks using platforms such as emails, chats, and the web, including audio and video conferencing. ELearningNC.gov defines online learning as learning by utilizing modern technology such as electronic devices and the internet to acquire syllabi, topics, and lessons outside the classroom.

Both Tavukcu, Arapa and Özcan (2011, p.4000) and Clark and Mayer (2011, pp.8) define e-learning as learning using modern technology such as electronic devices and the internet to access lessons outside the classroom, wherein the student logs in to the e-learning portal to access the lectures and other forms of education.

Mobile learning is slightly more targeted by Clark and Mayer (2011, p.8): mobile learning is also defined as categorized e-learning through a mobile device where the facilitator targets individuals in delivering the information. According to Perez-Guerrero, Monguet-Fierro and Saldaña-Garcia (n.d., p.285), mobile learning is a mode of learning that requires the use of mobile devices to facilitate learning. In this definition, the student and facilitator can interact 
anytime and anywhere using the mobile device. Moore, Dickson-Deane and Galyen (2011, p.130) include social and content sharing between teachers and also between fellow students.

\subsection{Definition of Emergency Learning}

According to Ferri, Grifoni and Guzzo (2020, p.86), emergency learning involves the use of remote teaching methods due to a crisis that hinders teacher-student classroom delivery. In this definition, a temporary education system is employed to prevent the negative impact of an interruption of student learning, as during the Covid-19 pandemic. Swan (2019, p.56) defines emergency learning as the attempt to re-enact the teacher-student classroom environment in an organized virtual classroom that requires the student to log into the class to access the contents. Hodges, Moore, Lockee, Trust and Bond (2020) add that emergency learning is where the teacher or the educators deliver learning instruction from a distance in a situation where the learners and educators cannot physically locate in their classroom.

Temporary online emergency learning is adopted due to a crisis, and the regular education resumes when the problem ends. Usually, temporary emergency learning involves online access that helps students acquire learning resources outside the classroom. Tavukcu, Arapa and Özcan (2011, p.4000) state that temporary online emergency learning maintains the student-teacher interaction during the period of the crisis, regardless of teachers and students being in different places. An equivalent concept was first introduced in 1919 wherein radio stations related to education were established. Through development in technology, digitally based online emergency learning is now in use. Temporary emergency learning was implemented in many areas of the world in 2020 during the Covid-19 pandemic wherein the education system was transformed to online for a period of time while students were compelled to learn away from school due to Covid-19 measures restricting movement and requiring social distancing (Ferri, Grifoni, \& Guzzo, 2020, p.86).

\section{Types of Distance/online Learning}

\subsection{Video Conferencing}

According to Clark and Mayer (2011, p.22), video conferencing is learning participants using video calls and chats to connect for learning. This form of education requires the internet and involves tools such as Zoom, which the teacher commonly uses to interact freely, regardless of the location of teacher or students.

\subsection{Hybrid Distance Education}

Tavukcu, Arapa and Özcan (2011, p.4000) define hybrid distance education as learning wherein a teacher offers take-home assignments and continuous assessment tests, with submission deadlines. This learning type allows the students to do the assigned tasks at their own pace and submit them by the due-date. Here the teacher-student interaction is online, and the assignment submission is made online.

\subsection{Open Schedule Online Courses}

This is a type of distance learning that enables students to apply, register and complete a 
course online. In open scheduled online classes, student performance is controlled by regulations that allow students freedom in when and how to access their classes, but specifies when and how work must be completed and submitted. (Clark and Mayer, 2011, p.31). The facilitator/instructor guides the students through online textbooks and emails. Here the students work at their own pace, and the individual student's performance is based on self-determination, self-drive, and dedication toward the course. These classes can be synchronous and/or asynchronous. The synchronous format allows greater interaction between teacher, students, and other students, but may be incompatible with some students' other obligations. These classes may be recorded and available for those who cannot login at the specified time, and those students can interact through online bulletin boards.

\section{Educational Response to the 2020 Pandemic}

School closures caused by the Covid-19 (coronavirus) pandemic have certainly affected students across the globe. The World Bank tracking tool shows that COVID-19 has generated an extreme crisis in the field of education as it is having the greatest negative impact in a century on the immense scale of the student population worldwide.

With the uncertainty of when this pandemic will end, the world still has 700 million students studying in an e-learning format, from hybrid to remote learning, and some with no schooling at all due to limited local resources. The sudden shift to online learning because of COVID-19 has forced unprepared educational systems to adopt different ways of learning, which has resulted in making educational outcomes even worse than before. It has been a global shock to find that the educational systems in most countries are not prepared to face this type of challenge. COVID-19 has exposed different problems and gaps in the current educational systems, many with no backup plans. Nearly every school in the world is in emergency-response mode. This is not surprising, given how suddenly this crisis arrived.

The education sector has experienced many changes due to the Covid-19 outbreak. To prevent the spread of the disease, schools have taken health measures which include enforced social distancing and prolonged institutional closures, both negatively impacting their students (Al Harthi et al., 2020). Many students have not had enough time to learn at home, and parents face the additional burden of struggling to find or become home-based teachers. Because this is something new, it has been harder for most of the younger students, especially kindergarten and lower elementary, to follow text-based or online instruction without parental help; at the same time, most of the parents are employees, trying to do their own work. With the extension of the period of school closures, education stakeholders have resorted to alternative learning options such as distance learning and online learning.

Through utilizing educational technologies to provide remote learning during the pandemic period, global organizations have worked closely with many countries to ensure that the learning process continues. Taking Argentina as a case study, we find that the World Bank and the Argentine government offered digital resources for administrators, teachers, and learners to facilitate remote learning (Bozkurt, Xiao, Vladimirschi, Schuwer, Egorov, \& Paskevicius, 2020). The national government employed television to promote broadcasting of the instructional process. Radio and television programs facilitated learning for those students 
who could not access technology and internet connectivity, (Dreesen et al., 2020).

Alternative means of education are not well supported in most low-income countries as the process requires an extensive internet network, which is a challenge in developing countries. Most governments in developed nations, such as Australia, have invested in computers to facilitate online and distance learning during the pandemic (Rasiah, Kaur, \& Guptan, 2020).

Just as in most nations across the globe, citizens in the United States are still finding it difficult to access education in equal measure, (Dorn, 2017). Since 2005, several challenges within the educational system have culminated in the current crisis. Some of these challenges include: lack of equal access to education, augmentation of school drop-out statistics, lack of enough technology in schools, and lack of reliable disciplinary policies (Cochran-Smith et al., 2017). However, in the event of emergencies such as natural disasters, epidemics and pandemics, and events of turbulence within the nation, schools are most affected because of a lack of effective plans to counter these disturbances (Dorn, 2017). Although the pandemic has afflicted the entire world, Covid-19 has also exposed an educational crisis in the United States of America.

In the United States, the pandemic has overwhelmed the functioning and outcome of the education system (Peters et al., 2020). According to Peters (2020), in the US, this has resulted in nearly 55 million children under the age of 18 staying in their homes, many without adequate online infrastructure. In addition to education, these children now have no access to basic support provided in schools such as group activities, recreation facilities, team sports and nutritional supplementation. The two main tools available for learning in the United States during the pandemic have been homeschooling and remote learning. Ideally, homeschooling is a system of education where parents instruct their school-aged children at home, choosing to teach their children themselves or hiring tutors and teachers to do the teaching in the home or other designated non-school setting (Gaither, 2019). On the other hand, remote learning, also known as distance learning, is a type of education where the learner and the educator are not physically present in a traditional class setting, but engage with each other through technological mediums (Carter et al., 2020). Because of emergencies such as the Covid-19 pandemic, for the safety of the nation, both homeschooling and remote learning are practiced in integration through internet and video conferencing technologies (Colucci et al., 2017). Several educational experts have raised the concern that school closures have created a situation where children from low income families are losing out on the opportunity to continue learning (Burde et al., 2017). The most common challenges faced by the disadvantaged children include the unavailability of digital devices and/or internet in their homes, and lack of adequate help and supervision if parents are working. Therefore, distance learning may be out of reach for the most vulnerable students. Distance learning for this demographic is also affected by lack of devices such as printers, stationery and craft materials.

Klaus (2014) argues that humanitarian crises impair educational opportunities and sometimes make education impossible. In countries such as Iran, Syria and Yemen, students' education has been devastated through years of war and political conflicts that have disrupted the 
normal learning process, leading to a huge gap between urban and rural populations (Ranjan \& Jain, 2009) Therefore, any humanitarian catastrophe represents an educational catastrophe. All plans of action to realize important educational objectives should integrate the issue of pedagogical intervention in areas impacted by the crisis. According to Nazarov (2011), such disasters should be the driving forces for new changes and enhancements to the sector. Integration of the latest technology helps a country to achieve robust disaster management that cushions it against future crises.

Kollender and Nimer (2020) claim that little attention is given to marginalized groups in government policies to address the COVID-19 pandemic. Colucci et al. (2017) believe that mobile phones and other technologies can be used to support the need for integrating the marginalized communities into the emergency programs. Bozkurt et al., (2020) also point out that social injustice, inequity, and a digital divide have been exacerbated during the pandemic. The current practices are different from planned practices, including online learning, distance education, and other derivations, in that they have not been carefully pre-planned to deal with these obstacles (Bozkurt et al., 2020).

The rapid closures of educational institutions across the world were done in the hope that following social distancing advice would flatten the curve of the pandemic and reduce total fatalities (Murphy, 2020). However, the world has experienced huge numbers of infections and deaths despite such measures, confronting the educational system with a new and massive crisis (D'Orville, 2020). Because many closures have had a serious impact on the mental health of educational staff and the careers of university students (Sahu, 2020), Creed $\&$ Morpeth (2014) argue that rather than full closure, a combination of face-to-face, distance, and flexible learning should be used to maintain a degree of continuity in education. However, such measures are ad hoc and bear limited fruit for the educational and psychological needs of the broad totality of the population they serve. There are questions of how the new normal should look for future generations. This situation calls for using the available resources in flexible ways to repair the damage done to the learning trajectories of the students (Daniel, 2020).

The current crisis can also be viewed as an opportunity for stronger institutional collaborations focusing on the delivery of digital-based solutions to the educational system (D'Orville, 2020). Efron and Efron (2020) claim that similar strict measures were imposed during the Spanish flu outbreak in 1919. However, unlike during the situation in 1919, the advancement in technology has allowed for rapid dissemination of important information, thus improving intervention efforts.

\section{Policies and Practices around the World}

\subsection{Algeria}

The government needs to set policies that enhance teaching and learning during the pandemic, especially through remote learning. Technological infrastructure that enables online learning needs to be improved throughout the country. (Bozkurt et al., 2020) 


\subsection{Australia}

There is a need to support public schools in remote learning to make certain no inequalities exist. Educators should increase the involvement of undergraduates in online learning to ensure that they can continue with studies during and after a pandemic. (Bozkurt et al., 2020)

\subsection{China}

Online learning is likely to cause inequality due to some students not having access to internet services and devices necessary for learning. Therefore, policymakers and the Ministry of Education should develop several strategies, such as radio and televised programs, and combine them to reach all students. (Bozkurt et al., 2020)

\subsection{The Czech Republic}

In the Czech Republic, the physical presence of students in school buildings was prohibited as a measure to control the spread of the virus. Schools were forced to adopt the use of technology for distance learning in compliance with the new regulations. The starting position for students' e-learning programs were different for various schools, as some were already accustomed to the use of technology, while others had little experience with it (Pavlas et al., 2021). Up to eleven percent of the learners were not involved in online learning due to various challenges manifested in their learning institutions and at home. After the restrictions were rescinded, students were able to go back to classes, but now schools, governments and parents are more prepared in case they have to return to online learning in the future.

\subsection{Egypt}

There is a need for adequate infrastructure to support the internet and to provide devices for e-learning purposes during a crisis. Provision of funds to students to allow for online learning is necessary, as is empowering educators to develop digital literacy programs. (Bozkurt et al., 2020)

\subsection{France}

Between March and May 2020, students in France were required by the state to use distance learning due to the prevailing Covid-19 pandemic. A majority of parents expressed that they felt their children had satisfactorily acquired knowledge through the online learning program and could use digital tools more easily than previously. However, most of the students in both middle and high school levels claimed that they encountered various material difficulties during the period (Rosenwald \& Fruchart, 2021). The teachers affirmed that students had made significant progress during this time and had gained more autonomy and mastery in digital tools. There is general optimism that the newly acquired knowledge will be beneficial in future learning activities.

\subsection{Ghana}

The government needs to capitalize on ICT in schools for teachers and students, and empower them to develop learning mechanisms. Since remote learning is difficult, students need to keep fit by carrying out physical exercises while engaging in self-learning (Bozkurt et 
al., 2020).

\subsection{India}

Policymakers need to establish e-learning plans that ensure educational institutions are equipped with the necessary infrastructure. They should provide students with access to infrastructure and financial aid while advancing the technological competency of teachers. (Bozkurt et al., 2020)

\subsection{Japan}

In Japan, the Ministries of Education, Culture, Sports, Science and Technology directed that all schools be closed on $2^{\text {nd }}$ March, 2020, following an advisory by experts to allow for observation on how the pandemic would progress in the following one to two weeks. This step was taken as a preventative measure to protect children from group infection. Upon the reopening of the schools, the government provided guidelines on possible factors that would necessitate additional temporary school closures (Ministry of Education, Sports and Culture, 2021). The strategy was effective at preventing infections among children in various levels of learning. The Ministry of Health and the Ministry of Education have been able to devise efficient and effective measures and strategies for protecting children in the future through guidelines for how schools would reduce the distribution of factors of infection and how the determination to temporarily close schools would be reached. The government should develop an action plan that provides alternative solutions for education during a crisis, and implement it. All schools are supposed to decide on an emergency framework that helps prepare for a crisis through the use of remote learning and equipping their teachers with IT skills, while enhancing self-directed learning for their students. (Bozkurt et al., 2020)

\subsection{Kenya}

The education sector needs to incorporate online learning at all levels of education to ensure that the students and teachers can shift to e-learning in cases of crises. Internet bundles need to be subsidized so that more students can afford them for learning. (Bozkurt et al., 2020)

\subsection{Namibia}

There is a need to increase internet connectivity and offer training to educators. The ICT department needs to incorporate online learning into the education system of the country. Institutions should plan for the digital transformation of teaching and learning so as not to be caught unprepared. (Bozkurt et al., 2020)

\subsection{The Philippines}

The country needs to improve its telecommunication systems to increase internet connectivity. Educational institutions should provide adequate opportunities for students, while teachers should train for online teaching. (Bozkurt et al., 2020)

\subsection{South Korea}

The South Korean government postponed the reopening of schools and encouraged the 
provision of online classes as a way of ensuring that students would be protected from Covid-19 infections. The government put measures in place to expand learning infrastructure and the amount of online content available. The Korean government also initiated plans to narrow the gap in the ability of learners to access learning content through online platforms so that no one would be at a disadvantage (Ministry of Education, 2021). This included a variety of support for disadvantaged children, for example, attending to emergencies in childcare services. Other measures included disinfecting schools and providing on-site support for learners and teachers. These measures were successful in providing that learners could continue with their studies at minimum risk to their health. In the future, the measures will also be beneficial in enabling the learning process to continue while offering protection for both teachers and learners. In addition, it was determined that the government should decide on introducing emergency remote learning to give teachers and students ample time for preparations. Teachers should be trained for effective remote teaching, while students should be engaged more in e-learning. (Bozkurt et al., 2020)

\subsection{Russian Federation}

It is suggested that the government develop a framework that ensures continuity of education in a crisis. There should be a smooth transition wherein educators are competent in delivering content to their students through the new modality. (Bozkurt et al., 2020)

\subsection{South Africa}

The education system is shifting from a brick and motor model to a virtual approach, and thus there is a need to invest in ICT infrastructure for schools. Educational institutions should train their educators for remote teaching to prepare for any eventualities. (Bozkurt et al., 2020)

\subsection{Sweden}

To effectively handle the Covid-19 pandemic in Sweden, the government developed the School at Home project, aimed at promoting knowledge acquisition from home. On $18^{\text {th }}$ March, 2020, the Swedish government issued a directive for all learning to be conducted online. The transition to online learning was swift, and stakeholders felt that it was crucial to be certain that learners continued accessing knowledge without the risk of infection (RISE Research Institutes of Sweden, 2021). The significant success of distance learning in Sweden can be attributed to the robust digital infrastructure that existed before the pandemic broke out. In some schools, teachers in the lower levels of classes were required to simultaneously teach both physically and remotely so that the students who could not attend classes could follow instruction through the internet. The strategy used by Sweden was effective because learning continued, and the schools and authorities are now better prepared in the event that other pandemics or interruptions occur in the future.

\subsection{Uganda}

The collaboration of education stakeholders with policymakers is necessary to guarantee that there are long-term plans for the sector, promoting the inclusion of remote learning through the enhancement of ICT infrastructures. (Bozkurt et al., 2020) 


\section{GCC Responses}

As stated above, in March, the World Health Organization declared Covid-19 a global pandemic. Consequently, the world's largest educational systems have been forced to find alternative solutions to the traditional learning environment, and many have shifted to online learning. GCC countries were affected in the same way as many other countries around the world. Their educational sectors were among the least prepared for a disruption. The coronavirus pandemic has impacted the GCC educational sectors both negatively and positively. The response to Covid-19 and the initial wave of lockdowns was intended to shut down schools for a limited time, but then all transformed entirely to online learning. In fact, some of these decisions might bring permanent changes to the mode of teaching for some institutions.

\subsection{Kuwait}

In Kuwait, public schools were closed from late February to October in the year of 2020 with no access to any form of learning. The Ministry of Education (MOE) disregarded all calls and initiatives from the general public to support the learning process and overcome the issues. At the same time, private schools continued educating students through distance learning. However, shifting to a total online learning environment was a new model that had not been adapted in Kuwait before for either private or public schools, due to the existing rules and regulations. The Ministry of Education in Kuwait resumed education through distance learning by using Microsoft Teams together with a separate platform built by the ministry to accommodate the new needs of the learning process. Kuwait continued distance learning for the new academic year 2021/2022.

\subsection{Kingdom of Saudi Arabia}

Saudi Arabia responded to the Covid-19 pandemic by closing down all schools for 97 days to protect learners and educators from infection. Provision for education in Saudi Arabia during the period that schools were closed was through alternative means including online resources, television broadcasts, and provision of instructional packages. However, the general feeling among education officials was that even though students were learning, they were not learning as much as they would on a normal schedule (Mann et al., 2021). The ministry in charge of education recommended techniques that would ensure the safety of students when schools would reopen, including the provision of hygienic conditions and the use of face masks and hand sanitizers for students and other personnel. The measures instituted by the government were effective in offering protection to students while at the same time ensuring that, as much as possible, they were benefitting from in-person instruction. These measures were also helpful because the country learned useful methods to mitigate negative impacts on education from pandemics or other future disruptions. It was further decided that when school closure is necessary, the Ministry of Education needs to develop strategies for continuing education without engendering a significant gap in student progress. It should collaborate with other education stakeholders in developing policies for learning during crisis times. 


\subsection{Oman}

School was suspended in all educational institutions in Oman as part of precautionary measures to prevent the spread of the epidemic. However, the educational sector highlighted the importance of applying distance education to continue the learning process and adopted that model. Due to the necessity of this type of learning for any emergency as an effective alternative to ensure the educational process, the Ministry will develop it further for the future. For the new academic year 2021-2022, officials in Oman opted for the blended learning model and focused on activating distance learning and facilitating a gradual return of students in some grades in public schools. The educational authorities announced the details of the plan by stating that the blended learning model was provisionally approved for high schools and public schools by dividing the students into two groups, comprising 50 percent of the total number of students in class at one time, with consideration of necessary social distancing. The first group is present on all days of one week, followed by the second group in the following week, with the alternating group continuing education remotely.

\subsection{United Arab Emirates}

In schools of the Emirates, hybrid learning was implemented to combine the use of remote learning and in-person learning based on the health situation. The Ministry wanted to ensure the safety of the staff and students of schools before the start of the new year, including in public and private schools and higher educational institutions.

Due to the high investment in the technical infrastructure of the education sector over the past decades, teachers in the UAE have shown high efficiency in dealing with the challenges posed since the beginning of the spread of the epidemic, through their speed of response and ability to adapt to emergency conditions without disruptions to the educational process. The UAE has applied the best international practices in e-learning, providing schools and institutions with digital infrastructure and preparing students and teachers through training to simplify the use of the system.

\subsection{Kingdom of Bahrain}

Distance learning is considered one of the basic changes adopted by the Kingdom of Bahrain to ensure continuity of learning, yet this type of learning was criticized by teachers and parents because of the difficulties it presented. After a year of online learning, schools and institutions are open for face-to-face learning with a consideration of the health advisories to maintain social distancing. Physical attendance is optional for the students, so they can choose to be face-to-face in the schools or to continue distance learning from home.

\section{Discussion}

It is apparent that the different responses of the education sectors around the world in general and the GCC in particular prove that there is no single perfect tool or method to recommend for all; rather it is more a set of policies. The main goal of this study is to highlight the specific role of educational policies in shaping more resilient educational systems that can cope with future crises. The take away from Covid-19 is not to elect which tool or approach 
is the ideal one; the goal is to plan how to create an innovative learning system that is able to manage learning continuity despite the situation. The 2020 disruption in education shook up the world's educational systems and identified gaps in the current policies. Some countries responded with quick solutions, but others took months due to the mode of their emergency response. Therefore, it is important to turn this crisis response into long-term improvements in education.

As seen in the previous studies, a number of countries tried to adapt their educational systems in this pandemic, but there has been a lack of flexibility in policies to enable the implementation of effective strategies within a reasonable time frame. Currently, we have only cast a slight light on this question as most countries are still trying different models in the effort to continue education during the pandemic. Covid-19 has created huge gaps in learning and exposed weak roots in the various educational systems.

\section{The Role of e-Learning Policy in Emergency Learning}

The application of e-learning is not a simple matter; a solid infrastructure on which to effectively build e-learning is necessary. It requires an integrated system of infrastructure and training; therefore, the development of an e-learning policy is needed to ensure that the system is prepared and that there is an effective implementation of that system. That policy will provide guidelines and encourage schools and teachers to create high-quality online instruction, modifying the content to fit the specific purpose at hand.

An essential part of the policy is to clarify the rules and identify the rights within the educational system. For instance, it is important to provide pedagogical and technical support to teachers. Also, rules and regulations should be considered and explained in terms of teacher/student privacy protection. In addition, schools should consider the accessibility standards for students and teachers, making clear what is expected to be universally available to both groups. Finally, tools, resources, and copyright rules must be defined in the e-learning policy.

Education policy will assist with the gradual introduction of integrated e-learning to the student, and schools will start developing and adopting the foundations of e-learning in order to make it an essential part of the educational process. Accordingly, in the event of an emergency, a smooth transition to alternative solutions will happen without disruption in education. Students and teachers will already be prepared, and regardless of the tool or the approach, education will continue with high quality outcomes.

There are many countries that considered themselves to be prepared for e-learning at the onset of the crisis, and it was implemented immediately for students; however, in many cases, it was an unfortunate beginning for the use of this system because it was clear later that the students, teachers, and even the parents were not sufficiently trained. A complete system begins with policy, planning, awareness, training and flexibility in decisions. It is within this context that education policy must be considered. 


\section{Conclusion}

All in all, this study has highlighted the need for developing e-learning policies that are objective, proactive and practical, in order to provide quality, flexible learning in diverse educational settings, regardless of the challenges. It is important for the GCC countries to build the foundational policy of e-learning first, in order to have a solid base, rather than randomly selecting a method or technology. Therefore, with strong, clear e-learning policies, the response to pandemics or emergencies will be quick to meet the students' needs, rather than to supply a one-size-fits-all solution for all students. The findings of this study draw from evidence of the impact of Covid-19 on the education sector, and the GCC countries' responses in solving their learning disruptions. This study targets policymakers in the educational field in the GCC, to provide a wake -up call after the Covid-19 crisis to navigate and change the educational policies that are the core principle for quality education. Clearly, post Covid-19, GCC countries cannot return exactly to pre-pandemic conditions, and this holds true for the learning process as well. We cannot accept these learning interruptions in the future. Currently, the world is changing and developing while the school systems often stay the same: unfortunately weak, with insufficient backup plans or support. The 2020 pandemic has demonstrated that fact.

We close this paper with the recommendation for the GCC countries to review and address their current policies. The urgency of improving the policies is necessary to provide long-term support for the frontline educators and professional experts to act objectively, independently and flexibly.

\section{References}

Al Harthi, I. S. Covide-19 \& Shifting from Traditional Teaching to E-learning; Design Courses in University of Technology and Applied Sciences. Retrieved from https://core.ac.uk/download/pdf/337387781.pdf

Al-Azazi, F. S., \& Min, F. (2017). The Levels of Availability of Electronic Learning Efficiencies of Yemeni Female Teachers. American Journal of Educational Research, 5(6), 660-676. DOI: 10.12691/education-5-6-12

Annetta, L. A., Folta, E., \& Klesath, M. (2010). V-Learning: Distance education in the 21st century through $3 D$ virtual learning environments. Springer Science \& Business Media. https://books.google.co.ke/books?hl=en\&lr=\&id=1 nyo4m9XQ20C\&oi=fnd\&pg=PR7\&dq=A nnetta+Leonard, +E.+F.+(2010). + V-]Learning:+Distance + education + in + the +21 st + century + th rough $+3 \mathrm{D}+$ virtual + learning + environments. + Springer + Science $+\% 26+$ Business + Media\&ots $=$ AAQxOUq8in\&sig=AVP-OuCjfPnDu3dTIDI7cf2RGLw\&redir_esc $=\mathrm{y} \# \mathrm{v}=$ onepage \&q\&f $=\mathrm{fal}$ se

Apple, M. W. (2020). Homeschooling, democracy, and regulation: An essay review of Homeschooling: The history and philosophy of a controversial practice. Education Review, 27. Retrieved from https://edrev.asu.edu/edrev/index.php/ER/article/viewFile/2931/967

Bozkurt, A., Jung, I., Xiao, J., Vladimirschi, V., Schuwer, R., Egorov, G., ... \& Paskevicius, M. 
(2020). A global outlook to the interruption of education due to COVID-19 pandemic: Navigating in a time of uncertainty and crisis. Asian Journal of Distance Education, 15(1), 1-126. Retrieved from http://www.asianjde.com/ojs/index.php/AsianJDE/article/view/462

Burde, D., Kapit, A., Wahl, R. L., Guven, O., \& Skarpeteig, M. I. (2017). Education in emergencies: A review of theory and research. Review of Educational Research, 87(3), 619-658. https://doi.org/10.3102/0034654316671594

Burns, M. (2011). Distance education for teacher training: Modes, models, and methods. Washington, DC: Education Development Center Inc. Retrieved from http://library.uog.edu.gy/eBooks/Distance_Education_for_Teacher_Training_by_Mary_Burns EDC.pdf

Carter Jr, R. A., Rice, M., Yang, S., \& Jackson, H. A. (2020). Self-regulated learning in online learning environments: strategies for remote learning. Information and Learning Sciences. https://doi.org/10.1108/ILS-04-2020-0114

Chambers, J., Barker, K., \& Rouse, A. (2012). Reflections on the UK's approach to the 2009 swine flu pandemic: conflicts between national government and the local management of the public health response. Health \& place, 18(4), 737-745. https://doi.org/10.1016/j.healthplace.2011.06.005

Clark, R. C., \& Mayer, R. E. (2016). E-learning and the science of instruction: Proven guidelines for consumers and designers of multimedia learning. John Wiley \& sons. Retrieved from https://books.google.co.ke/books?hl=en\&lr=\&id=v1uzCgAAQBAJ\&oi=fnd\&pg=PR17\&dq= Ruth + Colvin + Clark, + a. + M. $+(2011) .+$ Elearning + and + the + Science + of + Instruction: + Proven + Guidelines + for + Consumers. + John + Wiley $+\% 26+$ Son\&ots $=$ TNvGoChMch\&sig $=4$ fHJTP7SS DUSGXsuEL_GPVa9XC8\&redir_esc $=\mathrm{y} \# \mathrm{v}=$ onepage $\& \mathrm{q} \& \mathrm{f}=$ false

Cloete, N., Maassen, P., Fehnel, R., Moja, T., Gibbon, T., \& Perold, H. (Eds.). (2006). Transformation in higher education: Global pressures and local realities (Vol. 10). Springer Science \& Business Media. Retrieved from https://books.google.co.ke/books?hl=en\&lr=\&id=Mjk_VjgqoPAC\&oi=fnd\&pg=PR7\&dq=Cl oete + Nico, + M. + P. $+(2006) .+$ Transformation + in + Higher + Education: + Global + Pressures + and + Local + Realities. + Springer + Science + and + Business + Media $+($ vol +10$) .+\&$ ots $=$ ri7cDFOJ6Q\&si

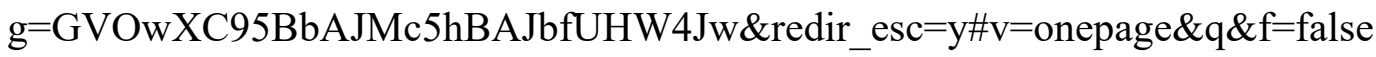

Cochran-Smith, M., Baker, M., Burton, S., Chang, W. C., Cummings Carney, M., Fernández, M. B., ... \& Sánchez, J. G. (2017). The accountability era in US teacher education: Looking back, looking forward. European Journal of Teacher Education, 40(5), 572-588. https://doi.org/10.1080/02619768.2017.1385061

Creed, C., \& Morpeth, R. (2014). Continuity education in emergency and conflict situations: The case for using open, distance and flexible learning. Retrieved from http://oasis.col.org/bitstream/handle/11599/1697/2014_JL4Dv1n3_CreedMorpeth_Continuity Education.pdf? sequence $=1 \&$ isAllowed $=\mathrm{y}$ 
d'Orville, H. (2020). COVID-19 causes unprecedented educational disruption: Is there a road towards a new normal?. Prospects, 49, 11-15. https://doi.org/10.1007/s11125-020-09475

Daniel, J. (2020). Education and the COVID-19 pandemic. Prospects, 49(1), 91-96. https://doi.org/10.1007/s11125-020-09464-3

Daniel, J. (2020). Education and the COVID-19 pandemic. Prospects, 49(1), 91-96. https://doi.org/10.1007/s11125-020-09464-3

Devi, L. L. (2017). Political Instability and Its influence on Higher Education: A study of students' perceptions in Manipur University. International Journal of Humanities and Social Science Studies (IJHSSS). A Peer-Reviewed bi-monthly Bi-lingual Research Journal, 3(5), 300-307. http://oaji.net/articles/2017/1115-1491480171.pdf

Dorn, C. (2017). For the common good: A new history of higher education in America. Cornell University Press. https://doi.org/10.1177/1521025118825106

Dreesen, T., Akseer, S., Brossard, M., Dewan, P., Giraldo, J. P., Kamei, A., ... \& Correa, J. S. O. (2020). Promising practices for equitable remote learning Emerging lessons from COVID-19 education responses in 127 countries (No. inores1090). Retrieved from https://www.unicef-irc.org/publications/pdf/IRB\%202020-10\%20CL.pdf

Dushkevych, M., Barabashchuk, H., \& Hutsuliak, N. (2020). Peculiarities of Student Distance Learning in Emergency Situation Condition. Romanian Journal for Multidimensional Education/Revista Romaneasca pentru Educatie Multidimensionala, 12. https://doi.org/10.18662/rrem/12.1sup2/248

Efron, N., \& Efron, S. E. (2020). Optometry in times of pandemic: Spanish flu (1919) versus COVID-19 (2020). Clinical \& Experimental Optometry, 103(4), 399. https://doi.org/10.1111/cxo.13094

Ferri, F., Grifoni, P., \& Guzzo, T. (2020). Online learning and emergency remote teaching: Opportunities and challenges in emergency situations. Societies, 10(4), 86. https://doi.org/10.3390/soc10040086

Gaither, M. (2009). Homeschooling in the USA: Past, present and future. Theory and Research in Education, 7(3), 331-346. https://doi.org/10.1177/1477878509343741

Hodges, C., Moore, S., Lockee, B., Trust, T., \& Bond, A. (2020). The difference between emergency remote teaching and online learning. Educause review, 27, 1-12. Retrieved from http://www.cetla.howard.edu/workshops/docs/The\%20Difference\%20Between $\% 20$ Emergenc y\%20Remote\%20Teaching\%20and\%20Online\%20Learning\%20_\%20EDUCAUSE\%20(2).p df

Hofmann, D. W. (2002). Internet-based distance learning in higher education. Tech Directions, 62(1), 28. Retrieved from https://eric.ed.gov/?id=EJ651646

Kollender, E., \& Nimer, M. (2020). Long-term exclusionary effects of covid-19 for refugee children in the German and Turkish education systems: A comparative perspective. Retrieved 
from https://ipc.sabanciuniv.edu/Content/Images/CKeditorImages/20200708-02075629.pdf

Kostelecká, Y., Ludvík, Z., Jancarík, A., \& Jancaríková, K. (2016, October). Distance learning and the home schooling in the Czech Republic. In European Conference on e-Learning (p. 364). Academic Conferences International Limited. Retrieved from https://www.oecd.org/education/Czech-republic-distance-learning-in-secondary-schools.pdf

Lustig, N., Lopez-Calva, L. F., \& Ortiz-Juarez, E. (2013). Declining inequality in Latin America in the 2000s: The cases of Argentina, Brazil, and Mexico. World development, 44, 129-141. https://doi.org/10.1016/j.worlddev.2012.09.013

Mann Anthony, S. M. (2021). How The Covid-19 Pandemic Is Cahanging Education: A Perspective fro Saudi Arabia. Ministry of Education, Sports and Culture. https://www.oecd.org/education/How-coronavirus-covid-19-pandemic-changing-education-S audi-Arabia.pdf

Moore, J. L., Dickson-Deane, C., \& Galyen, K. (2011). e-Learning, online learning, and distance learning environments: Are they the same?. The Internet and Higher Education, 14(2), 129-135. https://doi.org/10.1016/j.iheduc.2010.10.001

Murphy, M. P. (2020). COVID-19 and emergency eLearning: Consequences of the securitization of higher education for post-pandemic pedagogy. Contemporary Security Policy, 41(3), 492-505. https://doi.org/10.1080/13523260.2020.1761749

Nazarov, E. (2011). Emergency response management in japan. Azerbaijan: Crisis Management Center, Ministry of Emergency Situations of the Republic of Azerbaijan. Retrieved from https://www.adrc.asia/aboutus/vrdata/finalreport/2011A_AZE_Emin_FRR.pdf

Nikolopoulou, K. (2020). Preschool children's use of tablet at home and parents' views. In Mobile learning applications in early childhood education (pp. 209-229). IGI Global. https://doi.org/10.4018/978-1-7998-1486-3.ch011

Nurul Mostafa Kamal, Z. (2020). Sheikh Hasina Journal of Education in Emergency (SHJEiE)\|| Vol. 1, No. 1, Jan-Jun 2020. Sheikh Hashina Journal of Education in Emergency (2020). Retrieved from https://ssrn.com/abstract $=3660042$

Perez-Guerrero, M. L., Monguet-Fierro, J. M., \& Saldaña-García, C. (2011). Mobile Applications as Mobile Learning and Performance Support Tools in Psychotherapy Activities. In Handbook of Research on Mobility and Computing: Evolving Technologies and Ubiquitous Impacts (pp. 285-297). IGI Global. Retrieved from https://www.igi-global.com/chapter/mobile-applications-mobile-learning-performance/50593

Peters, M. A., Wang, H., Ogunniran, M. O., Huang, Y., Green, B., Chunga, J. O., ... \& Hayes, S. (2020). China's internationalized higher education during Covid-19: Collective student autoethnography. Postdigital science and education, 2, 968-988. https://doi.org/10.1007/s42438-020-00128-1

Ranjan, R. K., \& Jain, P. C. (2009). The decline of educational system in Iraq. Journal of 


\section{Macrothink}

peace studies, 16(1-2). Retrieved from http://www.icpsnet.org/pdf/1251368150.pdf

Rasiah, R., Kaur, H., \& Guptan, V. (2020). Business Continuity Plan in the Higher Education Industry: University Students' Perceptions of the Effectiveness of Academic Continuity Plans during Covid-19 Pandemic. Applied System Innovation, 3(4), 51. https://doi.org/10.3390/asi3040051

Sahu, P. (2020). Closure of universities due to coronavirus disease 2019 (COVID-19): impact on education and mental health of students and academic staff. Cureus, 12(4). https://doi.org/10.7759/cureus.7541

Saykili, A. (2018). Distance education: Definitions, generations, key concepts and future directions. International Journal of Contemporary Educational Research, 5(1), 2-17. Retrieved from http://ijcer.net/en/download/article-file/498240

Saykili, A. (2018). Distance education: Definitions, generations, key concepts and future directions. International Journal of Contemporary Educational Research, 5(1), 2-17. Retrieved from http://ijcer.net/en/download/article-file/498240

Seitz, K. (2004). Education and conflict: The role of education in the creation, prevention and resolution of societal crises-consequences for development cooperation;[Division 43, Health, Education, Social Protection]. GTZ. Retrieved from https://reliefweb.int/sites/reliefweb.int/files/resources/1F610940FB2A51B749256FFE001BD 784-EDandConflict-GTZ.pdf

Swan, K. (2019). Research on Online Learning. Online Learning. 11(1), 55-58. https://doi.org/10.24059/olj.v11i1.1736

Tavukcu, T., Arapa, I., \& Özcan, D. (2011). General overview on distance education concept. Procedia-Social and Behavioral Sciences, 15, 3999-4004. https://doi.org/10.1016/j.sbspro.2011.04.404

\section{Copyright Disclaimer}

Copyright for this article is retained by the author(s), with first publication rights granted to the journal.

This is an open-access article distributed under the terms and conditions of the Creative Commons Attribution license (http://creativecommons.org/licenses/by/4.0/). 